\title{
Archaeological Finds in the Kennet Gravels near Newbury
}

By Harold Peake, F.S.A., Local Secretary for Berkshire

So many discoveries have been made in the gravels of this region during the last few years, following upon a number which have been noted previously, that it seems advisable to treat them as forming a single body of evidence, which goes far to trace the evolution of the valley in Pleistocene and subsequent times.

The valley of the Kennet near Newbury runs from west to east, just north of the centre of the syncline between the Berkshire and Hampshire Downs. This syncline has been filled up with Reading and London clays, sometimes capped with a thin layer of Bagshot sands; but these have been partially denuded. The Eocene beds are at their thickest south of the Kennet Valley, but on the north they appear at a greater elevation, though the tributary streams have cut through these and left the chalk exposed.

All these Eocene beds are capped with plateau gravels, which have not as yet received the attention they deserve. They cover the ridges between the tributary valleys for five miles north of the Kennet, also the ridge dividing the Kennet Valley from that of the Enborne, which here runs parallel to it, and they extend for a considerable distance south of that stream.

The northern gravels seem to tilt gently southwards, and at their northern extremity lie with their base about $440 \mathrm{ft}$. O.D. ; there are, however, beds at a higher as well as at a slightly lower level. The main bed between the Kennet and the Enborne, on which lie Wash, Greenham, and Crookham Commons, falls to the east with the same dip as the Kennet, and south of Newbury lies about $400 \mathrm{ft}$. O.D. The Hampshire gravels seem to be at different levels, but some lie as high as $44^{\circ} \mathrm{ft}$. O.D.

The age of these gravels is at present uncertain. Those described above belong, with trifling exceptions, to the third stage of the plateau gravels of the Newbury region described by Mr. Osborne White; this he terms the Silchester and Greenham stage. ${ }^{.} \mathrm{He}$ places this in the earlier part of the Pleistocene

I The geology of the country around Hungerford and Newbury. Mem. Geol. Surv. Sheet 267, p. 93 . 
period. At the present moment these gravels are, in the absence of human evidence, undatable.

But in these gravels, as in the plateau gravels elsewhere, have been found certain palaeolithic implements, all of St. Acheul type. One of these, found by a boy from Newbury Grammar School on the roadside in a heap of gravel which had come from Brimpton pit, has already been described before the Society ; ${ }^{\text {I }}$ the level of the pit is $322 \mathrm{ft}$. O.D. Another implement of similar type is in the possession of Mr. A. D. Passmore; it was found in a gravelpit on Wash Common, but I am uncertain as to the exact position of the pit. A third came more recently from the garden of Crowshott, in the parish of Highclere, Hants, just below the surface soil in the upper layer of the gravel, found by Mr. Godfrey Arkwright; the altitude of the spot is $440 \mathrm{ft}$. O.D. The first and third of these are in the Newbury Museum, while a cast of the other has just been received from Mr. Passmore.

Were these implements lost when the Kennet was flowing at the $400 \mathrm{ft}$. level, as has been suggested by Crawford, ${ }^{2}$ or were they dropped upon the surface when the river had cut its channel to a lower level, as Macalister thinks ? ${ }^{3}$ If we knew the levels at which the implements had been found we could perhaps decide; unfortunately in two cases this is unknown, but Mr. Arkwright is clear that his was found on the top of the gravel. This looks as though Macalister were right, and that the gravel is older than the period of St. Acheul. Now Penck and Obermaier have maintained that the high gravels were laid down, beyond the limits of the glaciers, during successive Ice Ages If then we accept the usual view that the St. Acheul culture belongs to the latter part of the Riss-Würm interglacial period, then the Wash-Greenham-Crookham plateau gravel cannot be later than the Riss glaciation.

During the Würm glaciation, or immediately afterwards, the Kennet seems to have scoured out its present valley $160 \mathrm{ft}$. to $200 \mathrm{ft}$. below its former level. If any gravels were deposited during the Würm period, they were carried away by the floods that occurred as the ice began to melt. No terraces of this age have been found in the Kennet Valley, but there are lower terraces in the Enborne Valley which may belong to this time.

In due course the new bed of the Kennet was filled up with gravel to the depth of about $50 \mathrm{ft}$. This gravel is being dug at a pit close to Newbury station, and here have been found bones

I Proc. Soc. Antiq., xxxii, 87, 88.

2 Ibid., 88.

${ }^{3}$ R. A. S. Macalister, A text-book of European Archaeology, i, 262. 
which Dr. Andrews identifies as belonging to Bison priscus, Bos sp., Cervus elaphus, and Sus scrofa. According to Mr. E. P. Richards the same gravel, in the railway cutting a little to the west, yielded a tibia of Bos primigenius, a horn of Rangifer tarandus, and remains of Elephas primigenius. ${ }^{{ }^{2}}$ At other spots somewhat to the south and east Mr. L. T. Newton identified the remains of Bos primigenius, Bos taurus, Equus caballus, Ovis, Rangifer tarandus, and Sus scrofa, though it has been suggested that the remains of Ovis were perhaps of recent introduction. ${ }^{2} \mathrm{Mr}$. Osborne White distinguishes between the above beds, which he calls the lower terrace gravel, and others which he terms Low-level or Bottom gravels; there seem to be insufficient grounds for this distinction. ${ }^{3}$ The fine tusk of Elephas primigenius, obtained by Dr. Silas Palmer from the bed of the Kennet, seems also to have come from this gravel. ${ }^{4}$ It is in the Newbury Museum.

The fauna of this gravel, taken as a whole, seems to belong to the closing phase of the Pleistocene period. No implements have been found in it which can be considered as coeval. Mr. Richards mentions several worn tools, ${ }^{5}$ and a few much-abraded implements of Chelles type have recently been found in the pit by the station, and are now in the Newbury Museum. Considering the fauna, the plentiful occurrence of red-deer antlers and the single example of reindeer antler, we must, I think, equate this gravel with the period of La Madeleine, and perhaps with its later phases. If, as we have argued above, these gravels were laid down by the water derived from glaciers, this gravel must belong to the Bahl advance. This supposition seems to fit all the evidence available.

After an interval, in which ro $\mathrm{ft}$. to $20 \mathrm{ft}$. of gravel were swept away from the centre of the valley, a period seems to have followed when a deep channel, a quarter of a mile wide and $\mathrm{r} 2 \mathrm{ft}$. to $20 \mathrm{ft}$. deep, was cut through what was left, and filling this we find a deposit of peat. This must have been laid down in shallow lakes, when the flow of the river was slow and much impeded by gravel banks, and I have suggested elsewhere ${ }^{6}$ that

I White, op. cit. 99; E. P. Richards, The gravels and associated deposits at Newbury. Q. J. Geol. Soc., liii (1897). 425.

2 White, op. cit., 99; Richards, op. cit., 427 ; Trans. Newbury Dist. Field Club, iv (1 890), 210.

3 White, op. cit., 98,101 .

4 White, op. cit., 108 ; Trans. Newbury Dist. F. C., iii (1895), 193 ; foot-note by T. R. J. to Richards, op. cit., 427 .

5 E. P. Richards, The geology of Newbury and district, in Walter Money, $A$ popular History of Newbury (1905), 218.

${ }_{6}$ The Newbury Reginn. 
the formation of these lakes was due in no small measure to the action of beavers, which existed here as late as Saxon times. ${ }^{\mathrm{T}}$ The section made by Mr. Richards at the time of the laying down of the Newbury Sewage scheme shows a layer of shell-malm overlying the peat along Bartholomew and Northbrook Streets. ${ }^{2}$ Now this shell-malm seems to consist of débris of shells and other matter deposited by flood water upon the margins of the valley. Much of it is found by Marsh Benham and Speen Dairy Farm, and several feet of it were found overlying the gravel at St. George's Avenue. If we find a bed of shell-malm crossing the valley, there must have been something on which it could accumulate. This, I suggest, was a beaver-dam, and the fact that Professor W. Nielson Jones and Dr. M. C. Rayner found the pelvis of a young beaver in the peat just to the west of this line seems to support this view. A better-preserved dam of this type, also covered with shell-malm, and running nearly across the valley, may be seen at Marsh Benham.

The date of the peat is known approximately. Mr. C. E. P. Brooks has recently stated that it started about I 800 B.c. and lasted until A.D. $3 \mathrm{CO}^{3} \mathrm{Mr}$. Richards records neolithic flint implements from the peat and peaty soil at the sewage outfall works, ${ }^{4}$ but these, as we shall see later, may not have come from the peat. Two bronze spear-heads were found early in the nineteenth century in the peat on Speen Moor, ${ }^{5}$ and are now in the possession of Col. St. John, of Slinfold, Sussex, while a cheekpiece of a bridle, made of deer antler, was taken from the peat, or just above it, in West Street, Newbury, and is now in the Newbury Museum. These discoveries tend to support Mr. Brooks's contention, though, perhaps, he brings his final date down somewhat too late.

Recently some interesting flints have been discovered at the Borough Sewage Outfall Works in the parish of Thatcham, which help to fill in the gap between the valley gravel and the peat. The workmen were levelling a low bank when they discovered a number of flint flakes and a few small chipped pointed-butt celts. One of the latter and some of the flakes were taken to the

I Chron. Monast. Abingd. (Rolls Ser.), i, I 18.

2 Trans. Newbury Dist. Field Club, iv, pl. 2.

${ }^{3}$ C. E. P. Brooks, The evolution of climate in north west Europe. Q.J.R. Meteor. Soc., xlvii, 173.

4 Q. J. Geol. Soc., liii, 428-9.

5 The History of Newbury and its environs, Speenhamland (1839), 142 ; Evans, Bronze, 330, 333, 337 ; Journ. Brit. Arch. Ass., xvii, 322 ; V. C. H. Berks, i, I 95 , where they are erroneously described as three. 
museum, the remainder thrown away. An investigation of the site showed that these flints came from a deposit of black soil, full of flints, which overlay the valley gravel, but the discovery in the same deposit of Romano-British potsherds caused some perplexity.

Mr. O. G. S. Crawford and I undertook a systematic exploration of the site in September I92I, when the workmen found quantities of flint flakes and a few scrapers; they had in the meantime recovered most of the implements thrown away earlier. At one point, about $50 \mathrm{ft}$. from the other site, we dug a trench $30 \mathrm{ft}$. long, down to the valley gravel. ${ }^{x}$ This cleared up all obscurities.

We found surface soil to the depth of about I 2 in. to 2 I in., overlying a bed of compact peaty soil about 4 in. to $8 \mathrm{in}$. in thickness. Below this the soil was less compact for 8 in. to $10 \mathrm{in}$., and at the base of this was a layer of flints, on the top of the clean valley gravel, which was lying beneath. At one end of the trench was a deposit of clean white shell-malm resting partly on the peaty soil, which had been partially denuded at this point.

Six inches above the top of this peaty soil were the remains of three hearths, around which we found bones of oxen and RomanoBritish potsherds. The compact peaty soil was sterile, and at the base of the looser black soil below were numerous flint flakes and a few scrapers. On examination the clean valley gravel yielded no worked flints. It would appear that at the site first examined either the compact peaty soil was absent or very thin, and that the ground had been disturbed and the layers mixed when planting an osier bed.

A careful examination of the whole site showed that after the valley gravel had been considerably denuded, and its level reduced by about 20 feet, a layer of black soil full of flints had been laid down, perhaps by the river, or more probably by a small stream which joins it close by. It was at the beginning of this period that the low gravel bank was exposed as a small island above the marsh, and was used as a settlement or workshop by the flint workers. Subsequently the Kennet lowered its bed by about Io ft. to $20 \mathrm{ft}$., and this was again in the Bronze Age filled up with peat to its present level, which is $9 \mathrm{ft}$. below that of the settlement. Above the settlement a small pond formed before the valley level was lowered; in this also a bed of peaty soil accumulated.

I A full account of these excavations will appear in a forthcoming number of Proc. Prehist. Soc. East Anglia. 
We seem, then, to have the following stages :

I. Deposition of valley gravel.

2. Denudation of valley gravel.

3. Deposition of black soil with flints.

4. Further excavation of valley.

5. Deposition of peat.

6. Formation of shell-malm.
La Madeleine period.

Mas d'Azil period.

Campigny period.

Robenhausen period.

Bronze and Iron Ages.

Roman period and later.

At another spot a variety of objects have come to light. A company, Containers Limited, have been erecting a factory at Colthrop, in the parish of Thatcham, 4 miles east of Newbury. For the purpose of making concrete they have been digging several large pits, about $8 \mathrm{ft}$. to ro $\mathrm{ft}$. deep, in the floor of the valley, and the gravel, as far as they have gone, is very calcareous, containing a large quantity of small chalk pebbles, some blocks of peat over a foot in diameter, and a few trunks of uprooted trees. From one of the pits was dredged a bronze spear-head, dating from the close of period ii of Déchelette, and coeval with the longest bronze dirks, or rapiers as they are sometimes called. This, which was probably derived from the peat, fell into two pieces shortly after it was dredged up. It is impossible to say at what depth it had been lying.

In the most southern of the pits, but only a few yards distant from the spot at which the spear-head had been found, the workmen came across a wooden wheel, with an iron tyre, lying horizontally in the gravel at the depth of $5 \mathrm{ft}$. The wheel was perfect when discovered, but the wood was soft and spongy, and fell to pieces soon afterwards. Mr. F. C. Bertram Marshall, the engineer in charge of the works, saw it when it was found, and has described it to me. The outside of the hub expanded, and had a considerably larger diameter than the centre, the projecting piece being almost bell-shaped, with the larger end outside; the wooden rim or felloe was made in one piece. This wheel, from the description provided, seems quite unlike any which have been found with Iron Age associations, but bears some resemblance to the wheel of a Roman chariot found at Newstead, the felloe of which was also made in one piece. The tyre and fragments of the wood are in the Newbury Museum.

Near the wheel, and at the same depth, was found a human skull. This has been examined by Professor Parsons, F.S.A., who tells me that it resembles the skulls from the Long Barrows, but that it is slightly broader in the posterior region, but this extra breadth may be due to posthumous distortion, as the base of the skull has been broken away. 